\title{
$\mathrm{Al}-\mathrm{Mg}-\mathrm{Si}$ 系合金の曲げ加工性に及ぼす銅量の影響
}

\author{
浅野 峰生 ${ }^{*}$. 箕田 正 ${ }^{*}$. 小関 好和 ${ }^{*}$. 吉田 英雄 $*$
}

Journal of Japan Institute of Light Metals, Vol. 56, No. 7 (2006), pp. 371-375

\section{Effect of copper content on bendability of Al-Mg-Si alloy sheets}

\author{
Mineo ASANO*, Tadashi MINODA*, Yoshikazu OZEKI* and Hideo YOSHIDA*
}

\begin{abstract}
$\mathrm{Al}-\mathrm{Mg}-\mathrm{Si}$ alloys are used for automotive closure panels as a weight saving option. Improvement of the Al-Mg-Si alloy sheet bendability is required for better hemming performance. In this study, the effects of the copper content on the bendability of the $\mathrm{Al}-\mathrm{Mg}-\mathrm{Si}$ alloy sheets were investigated. The $\mathrm{Al}-\mathrm{Mg}-\mathrm{Si}$ alloys with less than 0.01 mass $\% \mathrm{Cu}, 0.4 \mathrm{mass} \% \mathrm{Cu}$ and $0.8 \mathrm{mass} \% \mathrm{Cu}$ were prepared, and the time of solution heat treatment was changed to obtain different dispersion conditions of the second phase particles and to obtain different shear band formation conditions by bending. For the samples with less than 0.01 mass $\% \mathrm{Cu}$ and 0.4 mass $\% \mathrm{Cu}$, no cracks were observed during the bending. For the sample with 0.8 mass $\% \mathrm{Cu}$, the maximum depth of the crack by bending increased with the time of solution heat treatment up to $75 \mathrm{~s}$, and then decreased over $75 \mathrm{~s}$. The second phase particles decreased with increasing the solution heat treatment time, while the number of shear bands by bending increased with increasing the solution heat treatment time and the copper content. The cause of the occurrence and the propagation of cracks by bending are considered to be the combined effect of the shear band formation in the grains and the micro-voids formed around the second phase particles. The improvement of the bendability requires a decrease in the size and number of the second phase particles and/or the restraint of the shear band formation during the bending.
\end{abstract}

(Received December 29, 2005 Accepted April 24, 2006)

Keywords: Al-Mg-Si alloy, bendability, second phase particles, shear bands, body panel

\section{1. 緒言}

自動車の軽量化を目的として，ボディパネルへのアルミニ ウム合金板の適用検討が進められている。これまで日本では $\mathrm{Al}-\mathrm{Mg}$ 系合金が主に用いられてきたが，塗装焼付硬化性を持 ち，リサイクル性にも優れた $\mathrm{Al}-\mathrm{Mg}-\mathrm{Si}$ 系合金の適用検討が 進められている。現に欧米では $\mathrm{Al}-\mathrm{Mg}-\mathrm{Si}$ 系合金がボディパ ネル用材料の主流となっている1,2)。

フード，ドア，トランク等のボディパネルにおいて，アウ ターパネルとインナーパネルをかしめる曲げ加工（ヘミング） を行うが， $\mathrm{Al}-\mathrm{Mg}-\mathrm{Si}$ 系合金は $\mathrm{Al}-\mathrm{Mg}$ 系合金と比較して曲げ 加工性が劣る。そのため, $\mathrm{Al}-\mathrm{Mg}-\mathrm{Si}$ 系合金について曲げ加 工性の改善が求められている。曲げ加工性については, 結晶 粒界に析出したシリコン相の影響3), 鉄量の影響4), マンガン 量の影響5) や，鉄量が多い場合のけい素量およびマンガン量 の影響6）等多くの報告がなされているが，銅添加の影響につ いて報告された例がない。一方，著者らは銅を添加していな い Al-Mg-Si 系合金において, 溶体化処理時間を変化させ, 曲げ加工性に及ぼす第 2 相粒子の影響について調査しており, 溶体化処理時間の増加に伴って第 2 相粒子数（主に粒内の第 2 相粒子数) が減少し, 曲げ加工時に著しいせん断帯の形成がみ られるようになること, 曲げ加工性は全第 2 相粒子数とせん 断帯の形成が共に多い場合に低下することを報告している7)。
そこで本研究では, $\mathrm{Al}-\mathrm{Mg}-\mathrm{Si}$ 系合金の銅添加量および溶 体化処理時間を変化させ, 曲げ加工性に及ぼす銅添加の影響 について調査を行った。

\section{2. 実験方法}

Table 1 に供試材の化学成分を示す。銅量 0.01 mass \% 未満 （銅の添加なし）および銅を 0.4 mass \% および 0.8 mass $\%$ 添加 した $\mathrm{Al}-\mathrm{Mg}-\mathrm{Si}$ 系合金を鋳造し, $550^{\circ} \mathrm{C}$ で均質化処理を行い, $500^{\circ} \mathrm{C} \sim 200^{\circ} \mathrm{C}$ の温度範囲内で熱間圧延を行った後, 冷間圧延 により $1.0 \mathrm{~mm}$ の板材とした。この冷間圧延板を塩浴炉にて $550^{\circ} \mathrm{C}$ で $15,45,75$ および $300 \mathrm{~s}$ の溶体化処理を行い, その後 水冷（冷却速度 $300^{\circ} \mathrm{C} / \mathrm{s}$ ）で焼入れを行った。焼入れ後, 常 温 $\left(20^{\circ} \mathrm{C}\right)$ で 7 日間保持した後に, 引張試験, 曲げ試験, 光 学顕微鏡観察, 走査電子顕微鏡観察, 透過電子顕微鏡観察を 行った。

引張試験は各供試材より圧延方向に対して平行方向に JIS 5 号引張試験片を採取し，インストロン型引張試験機を用いて 行った。曲げ試験は圧延方向に対して平行方向に長さ $200 \mathrm{~mm}$, 幅 $25 \mathrm{~mm}$ で切り出した板材に $15 \%$ 引張予ひずみを 加えた後, 押し曲げ法（JIS Z2248）により内側曲げ半径 $1.0 \mathrm{~mm}$ の 180 度曲げ試験を行った。曲げ部の割れ深さ（以 降，曲げ割れ深さ）測定はFig. 1 に示す方法で行った。曲げ 試験片の幅中央部付近で割れおよびしわが顕著な場所を目視

\footnotetext{
*住友軽金属工業(㑣研究開発センター（† 455-8670 名古屋市港区千年 3-1-12)。 Research \& Development Center, Sumitomo Light Metal Ind., LTD. (3-1-12. Chitose, Minato-ku, Nagoya-shi, Aichi 455-8670).E-mail: MINEO_ASANO@mail.Sumitomo-lm.co.jp
} 
Table 1 Chemical composition of specimens (mass \%)

\begin{tabular}{l|c|c|r|c|c|c}
\hline \hline \multicolumn{1}{c|}{ Alloys } & $\mathrm{Si}$ & $\mathrm{Fe}$ & $\mathrm{Cu}$ & $\mathrm{Mn}$ & $\mathrm{Mg}$ & $\mathrm{Al}$ \\
\hline$<0.01 \mathrm{mass} \% \mathrm{Cu}$ & 0.93 & 0.13 & $<0.01$ & 0.08 & 0.48 & Bal. \\
0.4 mass $\% \mathrm{Cu}$ & 0.90 & 0.10 & 0.36 & 0.08 & 0.44 & Bal. \\
0.8 mass $\% \mathrm{Cu}$ & 0.96 & 0.11 & 0.75 & 0.08 & 0.41 & Bal. \\
\hline
\end{tabular}

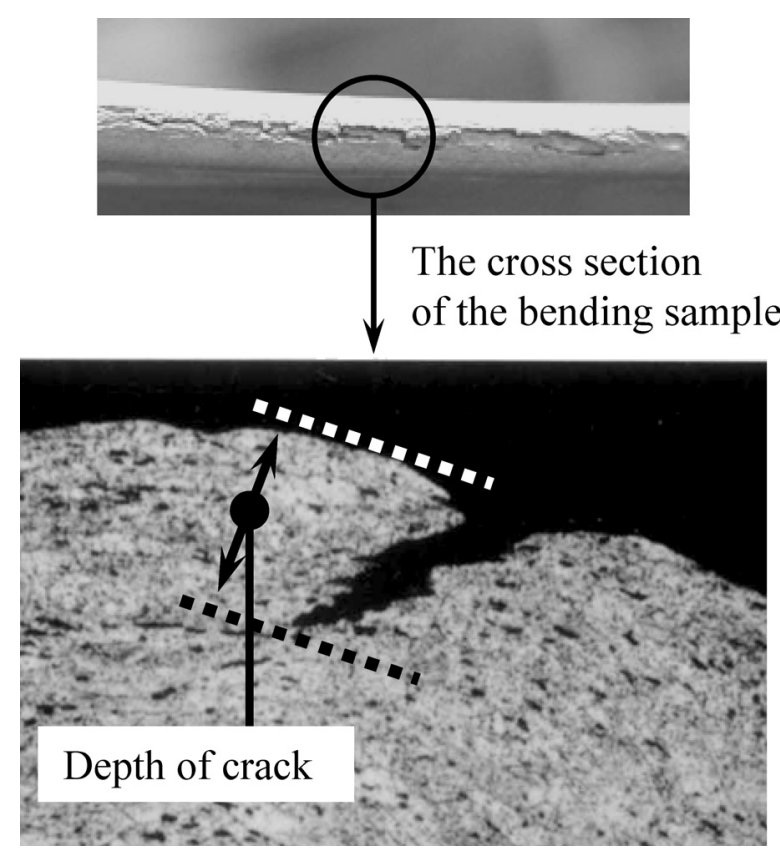

Fig. 1 Measurement method of the depth of crack by bending.

にて選び，その場所の断面を光学顕微鏡にて観察し，曲げ表 面から割れ先端までの最短深さを曲げ割れ深さとして測定し た。曲げ加工時に形成されたせん断帯の観察は曲げ割れ深さ を測定した試験片を用いて， $175^{\circ} \mathrm{C} て ゙ ~ 8 h$ の析出処理を行い， ケラー氏液を用いてェッチングを行った後, 光学顕微鏡を用 いて行った。

第 2 相粒子分布については，L-ST 断面（板幅方向之垂直 な面）の光学顕微鏡組織観察（観察倍率 400 倍）を行うとと むに, 画像解析装置による粒子サイズの定量測定（測定領域 $0.1 \mathrm{~mm}^{2}$ ) を行った。第 2 相粒子の成分分析は EPMA を用い て行った。結晶粒界上の第 2 相粒子観察は透過電子顕微鏡を 用いて行った。

\section{3. 結果および考察}

\section{1 供試材の曲げ加工性と機械的特性}

Fig. 2 に各供試材の曲げ割れ深さと溶体化処理時間の関係 を示す。銅量 0.01 mass $\%$ 未満, および銅を 0.4 mass $\%$ 添加し た場合，いずれの溶体化処理時間においても曲げ割れは発生 しなかった。一方, 銅を 0.8 mass \% 添加した場合, 溶体化処 理時間 $15 \mathrm{~s}$ では曲げ割れの発生はなく, 溶体化処理時間の増 加とともに曲げ割れ深さは増加し, 溶体化処理時間 $75 \mathrm{~s}$ で最 大値を示した後，減少した。

曲げ加工性には各供試材の機械的特性值（特に強度および 延性）が影響すると考えられる。高木ら ${ }^{8)}$ は曲げ加工性と引 張特性值の相関について調査しており, 耐力の増加に伴って 曲げ加工性は低下すること, 伸びの増加に伴う曲げ加工性の

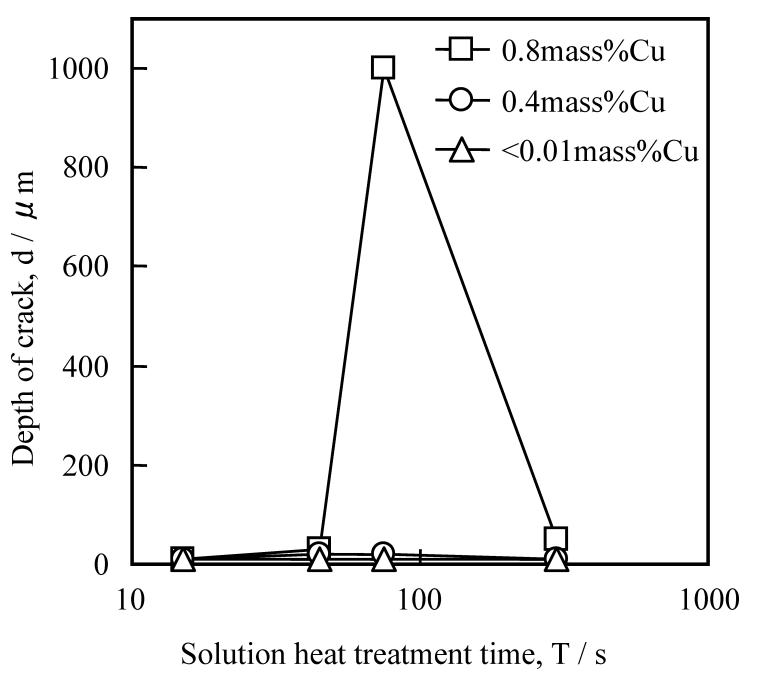

Fig. 2 Effect of solution heat treatment time on the distance from the bent surface to the top of the crack.

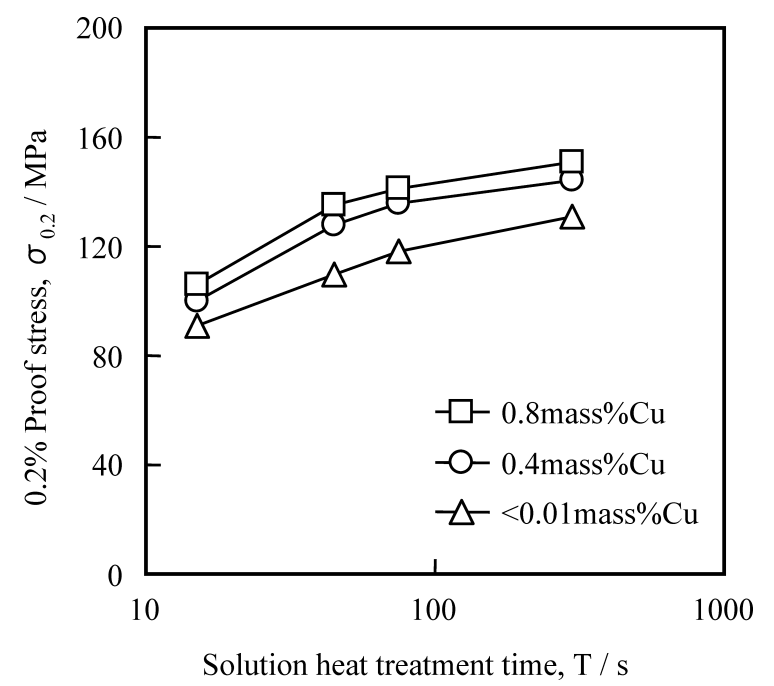

Fig. 3 Effect of solution heat treatment time on $0.2 \%$ proof stress.

向上はみられないことを報告している。そこで, 曲げ加工性 と耐力の相関を調查するため，各供試材の耐力を測定した。

Fig. 3 に各供試材の耐力と溶体化処理時間の関係を示す。 いずれの供試材においても溶体化処理時間の増加に伴って耐 力は増加した。いずれの溶体化処理時間においても銅添加量 の増加に伴って耐力は増加した。Fig. 2 において, 顕著な曲

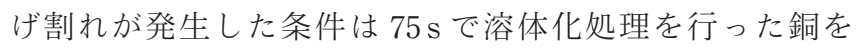
$0.8 \mathrm{mass} \%$ 添加した供試材のみであり, 曲げ加工性と耐力に 相関はみられなかった。

\section{2 銅添加量の影響}

前報7) で曲げ加工性は全第 2 相粒子数（主に粒内の第 2 相 粒子数）とせん断帯の形成が共に多い場合むしくは結晶粒界 上の第 2 相粒子数とせん断帯の形成が共に多い場合に低下す ることを明らかにした。そこで, 曲げ加工性に及ぼす銅添加 量の影響を明らかにするため, 各銅量を添加した供試材で曲 げ割れ深さに差のみられた溶体化処理時間 $75 \mathrm{~s}$ における全第 2 相粒子分布測定, 結晶粒界上の第 2 相粒子観察およびせん 断帯形成状態の観察を行った。

Fig. 4 に銅量 $0.01 \mathrm{mass} \%$ 未満の供試材および銅を 


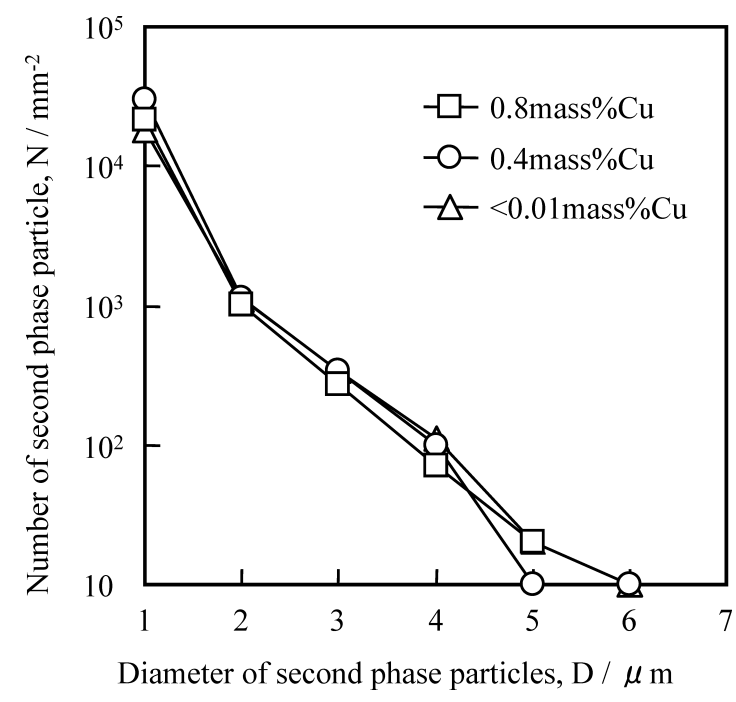

Fig. 4 Effect of copper content on the number of second phase particles after solution heat treatment at $550^{\circ} \mathrm{C}$ for $75 \mathrm{~s}$.

0.4 mass \% および 0.8 mass \% 添加した供試材の溶体化処理時 間 $75 \mathrm{~s}$ における全第 2 相粒子分布を示す。全第 2 相粒子分布 に及ぼす銅添加量の影響はみられなかった。

Fig. 5 に銅量 0.01 mass $\%$ 未満の供試材および銅を $0.4 \mathrm{mass} \%$ および $0.8 \mathrm{mass} \%$ 添加した供試材の溶体化処理時 間 $75 \mathrm{~s}$ における透過電子顕微鏡組織を示す。いずれの供試材 においても結晶粒界上の第 2 相粒子サイズおよび数に差はみ られなかった。

Fig. 6 に銅量 0.01 mass $\%$ 未満の供試材および銅を 0.4 mass \% および 0.8 mass \% 添加した供試材の溶体化処理時 間 $75 \mathrm{~s}$ における曲げ試験片断面の光学顕微鏡組織を示す。銅 添加量の増加に伴ってせん断帯の形成が観察された (矢印)。 ここでせん断帯とは光学顕微鏡で観察されるレベルの隣り合

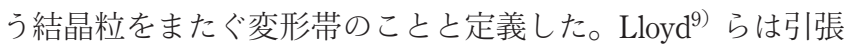
変形後の AA1100-O とAA2036-T4 において，AA2036-T4には AA1100-O で観察されないバンド状の転位構造が観察される と報告しており，これは固溶銅の影響と考えられる。また， Sachdev ${ }^{10)}$ は変形の限界ひずみレベルにおいて, バンド状の 転位構造はせん断帯まで成長すると報告している。

このことから，銅添加量の増加に伴って溶質原子量が増加 し，せん断帯の形成が著しくなったと考えられる。

以上のことから，各銅量を添加した供試材で溶体化処理時 間 $75 \mathrm{~s}$ において，曲げ加工性に影響を及ぼす全第 2 相粒子, 結晶粒界上の第 2 相粒子およびせん断帯の形成状態を調査し た結果, 差が認められた因子はせん断帯の形成状態のみであ り, 銅添加量の増加に伴ってせん断帯の形成が顕著になる様 子が観察された。よって, 溶体化処理時間 $75 \mathrm{~s}$ において, 銅 量 $0.01 \mathrm{mass} \%$ 未満の供試材および銅を $0.4 \mathrm{mass} \%$ 添加した供 試材で曲げ割れは発生せず，銅を 0.8 mass \% 添加した供試材 のみ曲げ割れが発生したのは, 銅添加量の増加とともにせん 断帯が形成されやすくなったためと考えられる。さらに，曲 げ加工中にせん断帯へ銅が濃化し, せん断帯に沿って破壊し やすくなる可能性む考えられるが，この詳細については今後 の検討課題にしたい。
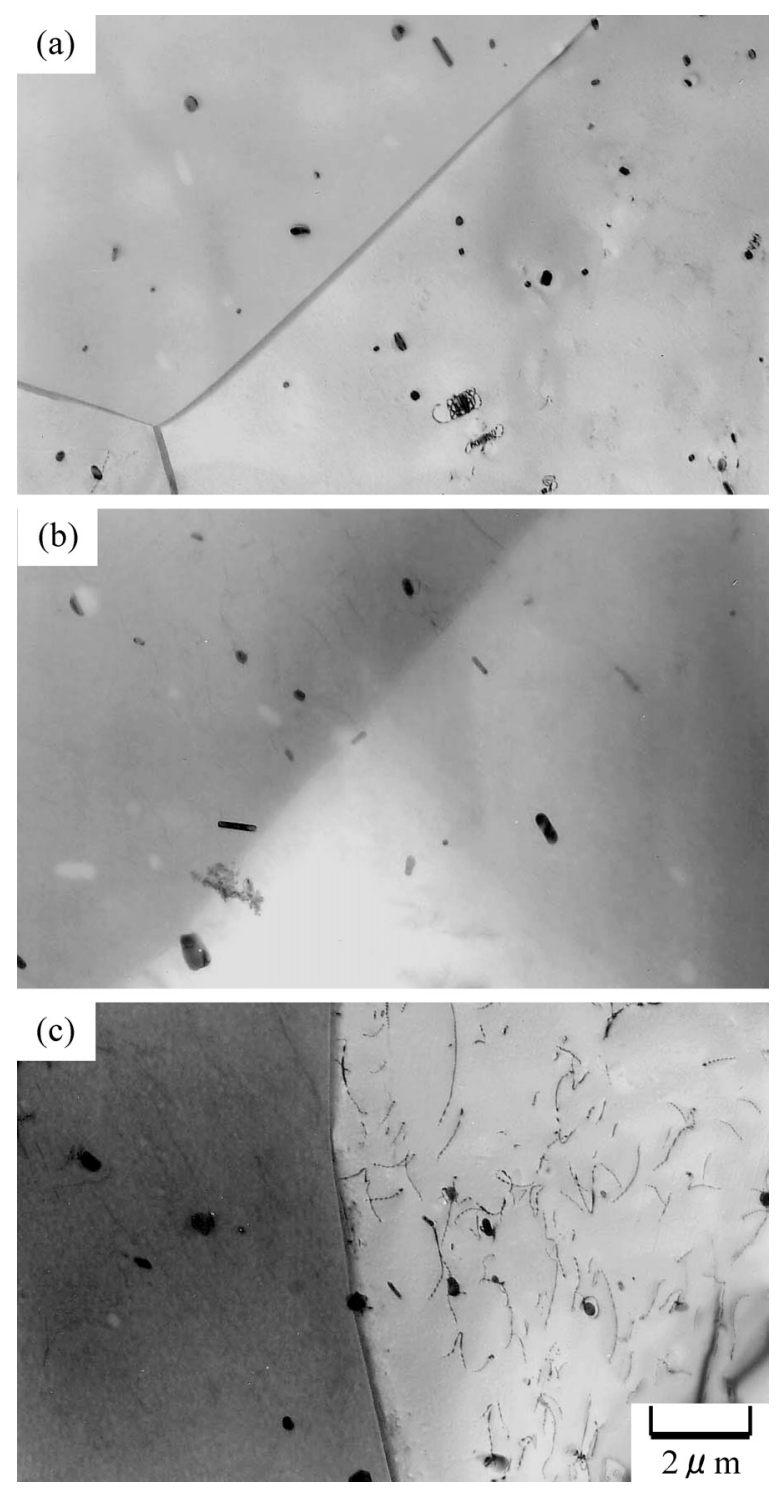

Fig. 5 Transmission electron micrograph structures after solution heat treatment at $550^{\circ} \mathrm{C}$ for $75 \mathrm{~s}$. The copper contents were (a) $<0.01$ mass $\%$, (b) $0.4 \operatorname{mass} \%$, (c) $0.8 \operatorname{mass} \%$.

\section{3 銅添加量 0.8 mass\%における溶体化処理時間の影響}

溶体化処理時間 $75 \mathrm{~s}$ で曲げ割れの発生した銅を 0.8 mass \% 添加した供試材において, 曲げ加工性に及ぼす溶体化処理時 間の影響を明らかにするため, 溶体化処理時間 $15 \mathrm{~s}, 75 \mathrm{~s}$ およ び 300 s における全第 2 相粒子分布測定, 結晶粒界上の第 2 相粒子観察およびせん断帯形成状態の観察を行った。

Fig. 7 に銅を 0.8 mass \% 添加した供試材の溶体化処理時間 $15 \mathrm{~s}, 75 \mathrm{~s}$ および $300 \mathrm{~s}$ における全第 2 相粒子分布を示す。溶体 化処理時間の増加に伴って $3 \mu \mathrm{m}$ 以上の第 2 相粒子が減少し た。銅量 0.01 mass $\%$ 未満の供試材および銅を 0.4 mass $\%$ 添加 した供試材においても同様の傾向が見られており, Fig. 4 で 示したように銅添加量の影響は見られなかった。Fig. 8 に銅 を 0.8 mass \% 添加した供試材および銅量 0.01 mass $\%$ 未満の供 試材の溶体化処理時間 $15 \mathrm{~s}$ および $300 \mathrm{~s}$ における EPMA 分析 結果を示す。銅を 0.8 mass \% 添加した供試材において, 溶体 化処理時間の増加に伴って減少した第 2 相粒子は $\mathrm{Al}-\mathrm{Mg}-\mathrm{Si}-\mathrm{Cu}$ 系化合物 (白色矢印) および $\mathrm{Mg}-\mathrm{Si}$ 系化合物 

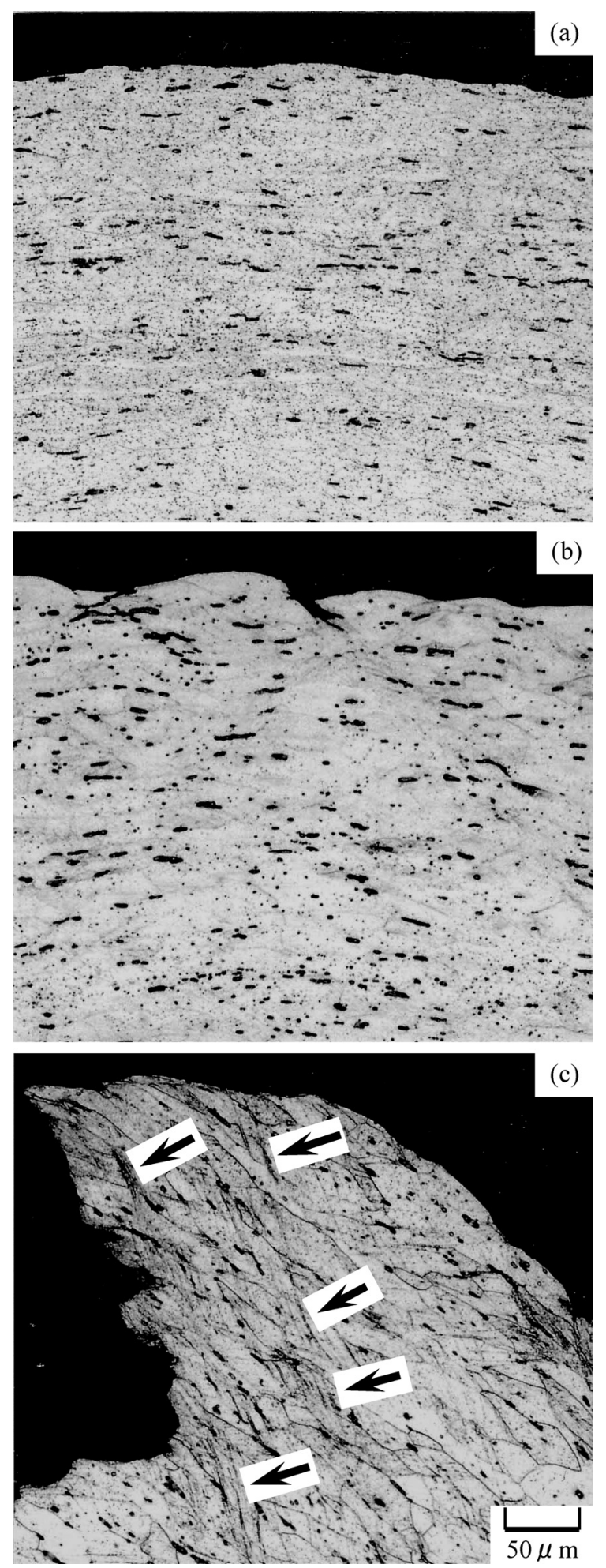

Fig. 6 Microstructures of the specimens after the bending test. The solution heat treatment was carried out at $550^{\circ} \mathrm{C}$ for $75 \mathrm{~s}$, and the copper contents were (a) $<0.01 \operatorname{mass} \%$, (b) $0.4 \operatorname{mass} \%$, (c) $0.8 \operatorname{mass} \%$.

（黄色矢印）であった。銅量 $0.01 \mathrm{mass} \%$ 未満の供試材におい て, 溶体化処理時間の増加に伴って減少した第 2 相粒子は $\mathrm{Mg}-\mathrm{Si}$ 系化合物 (黄色矢印) およびシリコン相（赤色矢印） であった。

Fig. 9 に銅を 0.8 mass \% 添加した供試材の溶体化処理時間 $15 \mathrm{~s} ，$ および $300 \mathrm{~s}$ における透過電子顕微鏡組織を示す。いず れの供試材においても結晶粒界上の第 2 相粒子サイズおよび

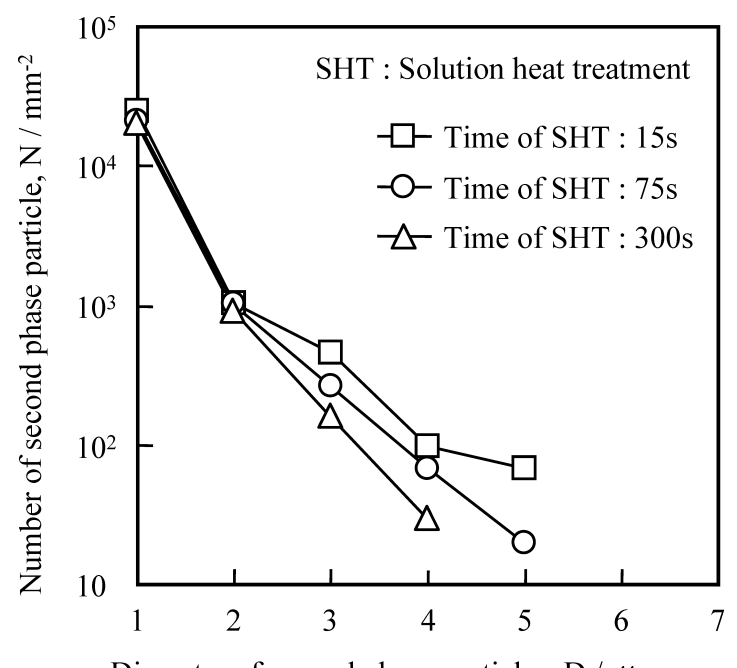

Diameter of second phase particles, D / $\mu \mathrm{m}$

Fig. 7 Effect of solution heat treatment time on the number of second phase particles of 0.8 mass $\% \mathrm{Cu}$.
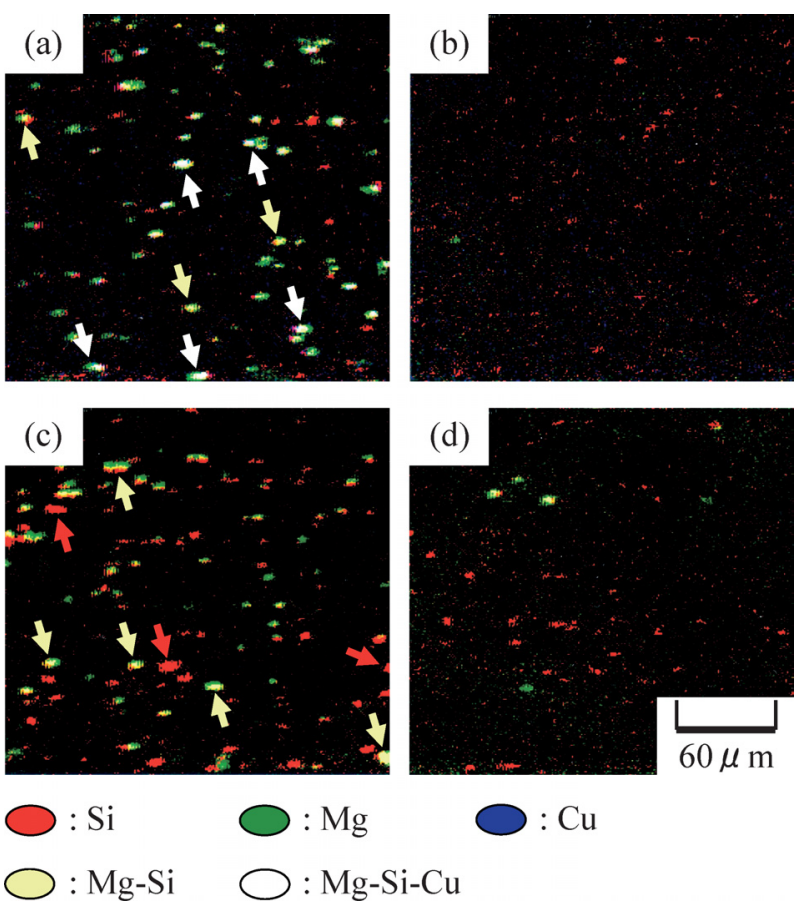

Fig. 8 Elementary analysis mapping of second phase particles by EPMA, (a) 0.8 mass $\% \mathrm{Cu}$ at $550^{\circ} \mathrm{C}$ for $15 \mathrm{~s}$, (b) 0.8 mass $\% \mathrm{Cu}$ at $550^{\circ} \mathrm{C}$ for $300 \mathrm{~s}$, (c) $<0.01$ mass $\% \mathrm{Cu}$ at $550^{\circ} \mathrm{C}$ for $15 \mathrm{~s}$, (d) $<0.01$ mass $\% \mathrm{Cu}$ at $550^{\circ} \mathrm{C}$ for $300 \mathrm{~s}$.

数に差はみられなかった。なお，前報7) で銅量 $0.01 \mathrm{mass} \%$ 未 満の供試材を用いて, 結晶粒界上の第 2 相粒子サイズおよび 数に及ぼす溶体化処理時間および焼入れ条件の影響を調査し ており, 溶体化処理後の焼入れ条件が同じ場合, 結晶粒界上 の第 2 相粒子サイズおよび数に及ぼす溶体化処理時間の影響 はみられないことを確認している。

Fig. 10 に銅を 0.8 mass \% 添加した供試材の溶体化処理時 間 $15 \mathrm{~s}$, および $300 \mathrm{~s}$ における曲げ試験片断面の光学顕微鏡組 織を示す。溶体化処理時間 $15 \mathrm{~s}$ において, 変形帯の形成は観 察されるが, せん断帯（隣り合う結晶粒をまたぐ变形帯）の 形成は少ない。溶体化処理時間 300sにおいてはせん断帯の 形成が多くなった (知)。 

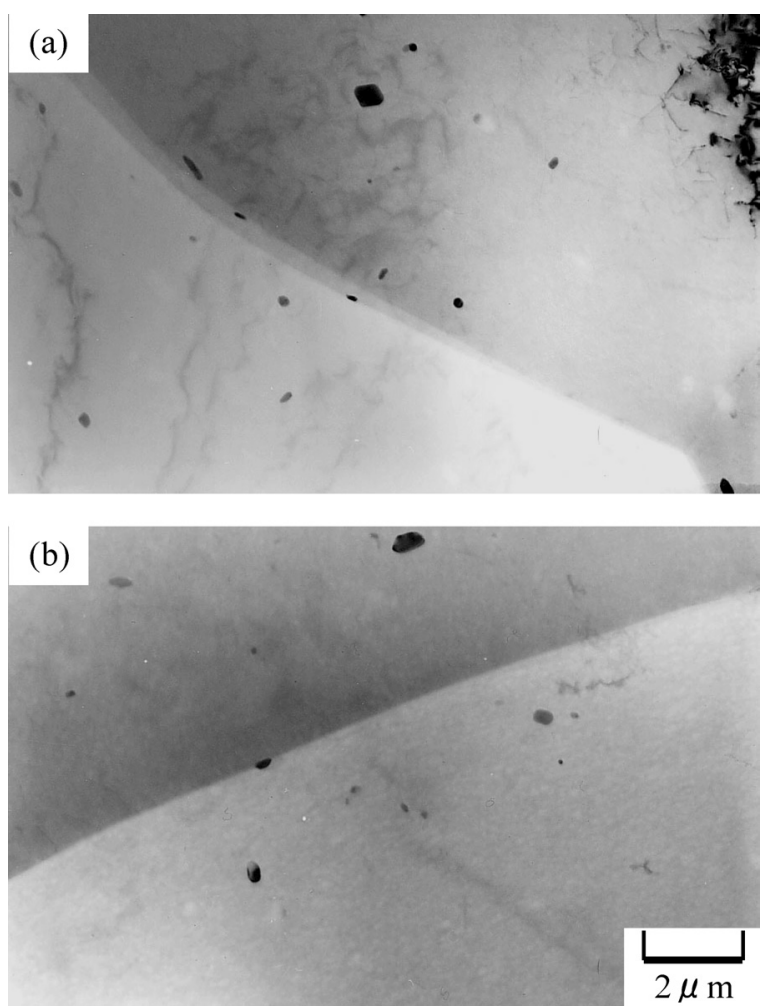

Fig. 9 Transmission electron micrograph structures of the sample with 0.8 mass $\% \mathrm{Cu}$, and the solution heat treatments were carried out at (a) $550^{\circ} \mathrm{C}$ for $15 \mathrm{~s}$, (b) $550^{\circ} \mathrm{C}$ for $300 \mathrm{~s}$.

以上のことから，銅を 0.8 mass \% 添加した供試材において， 曲げ加工性に影響を及ぼす全第 2 相粒子, 結晶粒界上の第 2 相粒子およびせん断帯の形成状態を調査した結果, 差が認め られた因子は全第 2 相粒子およびせん断帯の形成状態であり, 溶体化処理時間の増加に伴って $3 \mu \mathrm{m}$ 以上の第 2 相粒子が減 少し，銅添加量の増加に伴ってせん断帯の形成が多くなった。 よって, 銅を 0.8 mass \% 添加した供試材において, 溶体化処 理時間 $15 \mathrm{~s}$ で曲げ割れが発生しなかったのは，全第 2 相粒子 数は多いが，せん断帯の形成が少なかったためと考えられる。 溶体化処理時間 $75 \mathrm{~s}$ で曲げ割れ深さが大きかったのは全第 2 相粒子数之せん断帯の形成が共に多かったためと考えられる。 溶体化処理時間 $300 \mathrm{~s}$ で曲げ割れ深さが大きく減少したのは せん断帯の形成は多いが，全第 2 相粒子数が減少したためと 考えられる。なお，前報7) で銅量 0.01 mass $\%$ 未満の供試材に おいて, 曲げ試験での内側曲げ半径を $0 \mathrm{~mm}$ (密着曲げ) と して同様の結果が得られており, 溶体化処理時間 $75 \mathrm{~s}$ 付近に おいて, 第 2 相粒子が多く存在し, かつせん断帯の形成が著 しく，曲げ割れ深さは最大值を示すことが明らかとなってい る。

\section{4. 結言}

$\mathrm{Al}-\mathrm{Mg}-\mathrm{Si}$ 系合金の銅添加量を変化させ，曲げ加工性を調 査した結果，以下の結論を得た。

（1）いずれの溶体化処理時間においても銅量 0.01 mass \%未 満および銅を 0.4 mass\% 添加した場合，曲げ割れは発生しな かった。一方，銅を 0.8 mass \% 添加した場合，溶体化処理時 間 $15 \mathrm{~s}$ では曲げ割れの発生はなく, 溶体化処理時間の増加之 ともに曲げ割れ深さは増加し, 溶体化処理時間 $75 \mathrm{~s}$ で最大值
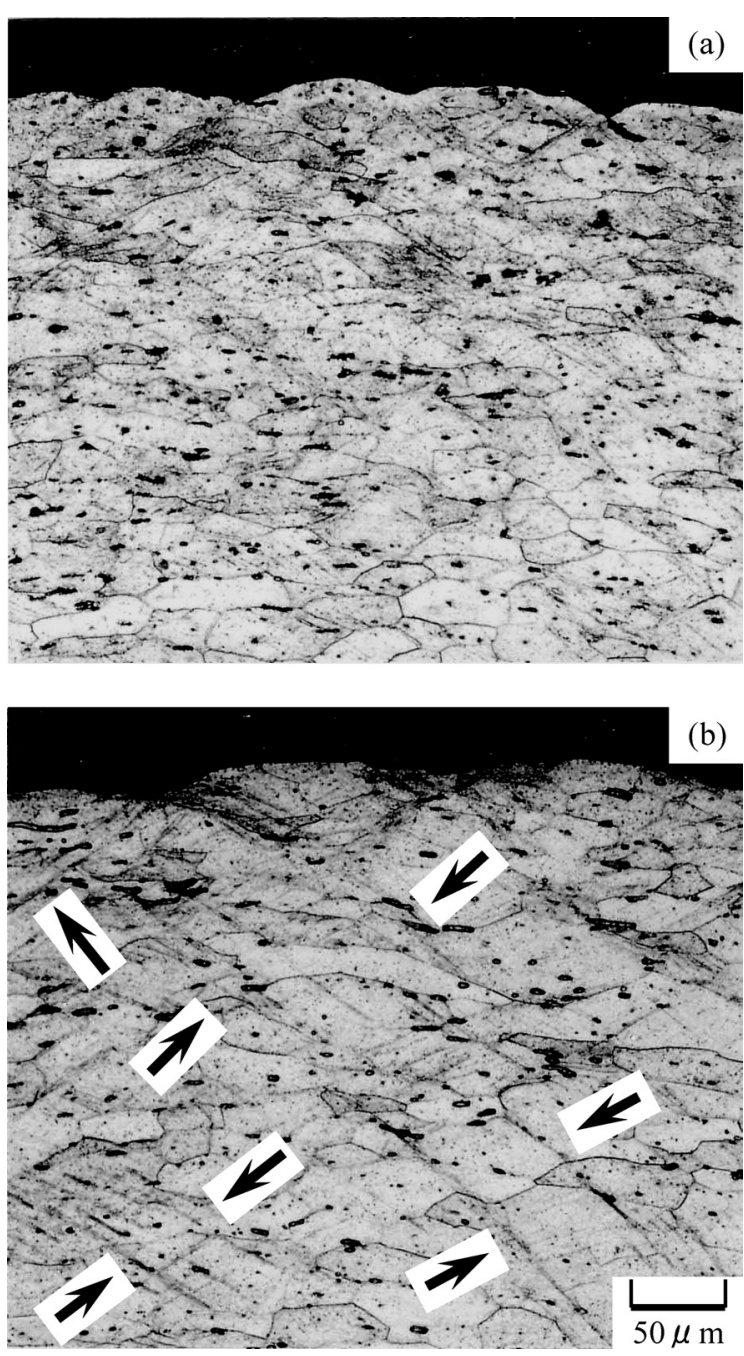

Fig. 10 Microstructures of the specimens after the bending test of the sample with 0.8 mass $\% \mathrm{Cu}$, and the solution heat treatments were carried out at (a) $550^{\circ} \mathrm{C}$ for $15 \mathrm{~s}$, (b) $550^{\circ} \mathrm{C}$ for $300 \mathrm{~s}$.

\section{を示した後，減少した。}

（2）溶体化処理時間 $75 \mathrm{~s}$ での銅添加量の増加による曲げ加 工性の低下は銅添加量の増加に伴って溶質原子量が増加し, せん断帯の形成が容易になったことが主因と推測された。

（3）銅を $0.8 \mathrm{mass} \%$ 添加した供試材における溶体化処理時 間 $75 \mathrm{~s}$ での曲げ加工性の低下は全第 2 相粒子数とせん断帯の 形成が共に多かったことが原因と考えられた。

\section{参 考 文 献}

1）西村嘉彦：金属, 65 (1995), 1194.

2）たとえば，宇野照生：アルミニウムの製品と製造技術，軽金属 学会, (2001), 220-247.

3）佐賀 誠, 佐々木行雄, 川崎 薰, 菊池正夫, 朱 岩, 松尾 守：軽金属学会第 90 回春期大会講演概要，(1996)，285-286.

4）箕田 正, 内田秀俊, 淽江和久, 吉田英雄：軽金属, 53 (2003), 523-527.

5）趙 丕植：軽金属, 55 (2005), 227-232.

6）箕田 正, 浅野峰生, 吉田英雄：軽金属, 55 (2005), 222-226.

7）浅野峰生, 内田秀俊, 吉田英雄 : 軽金属, 52 (2002), 448-452.

8）高木康夫, 竹添 修, 林 登, 安永晋拓：軽金属学会第 91 回 秋期大会講演概要, (1996), 31-32.

9) D. J. Lloyd and H. Sang: Metall. Trans. A, 10A (1979), 1767-1772.

10) A. K. Sachdev: Metall. Trans. A, 21A (1990), 165-175. 